\title{
THE FIRST PILOT STUDY OF BLACK FLY (DIPTERA: SIMULIIDAE) BREEDING SITES IN MOLDOVA
}

\author{
Vasiliev Alexandr, Șuleșco Tatiana \\ Institute of Zoology, MCER, Chisinau, Republic of Moldova \\ e-mail: vasilievalexandr@yahoo.com; e-mail:tatiana_sulesco@yahoo.com
}

https://doi.org/10.53937/9789975315975.66

\begin{abstract}
The data on black fly fauna in Moldova are absent in the old and modern literature. Overall, 45 black fly species from the genera Prosimulium (four species) and Simulium (41 species) are common both for Romania and Ukraine and expected to be present in Moldova. For the first time cross-sectional entomological survey was conducted in 2018 to detect the breeding sites of Simuliidae in Moldova. Productive breeding sites of black flies were identified in the creek close to the Dniester River section located in Vascauti village, Racovat River sections located in Branzeni and Burlanesti villages. Immature stages of black flies also have been found in the small creeks in Chisinau and Duruitoarea Veche.
\end{abstract}

Key words: black fly, Simuliidae, Republic of Moldova

\section{INTRODUCTION}

Black flies (Diptera: Simuliidae) are found almost everywhere with running water suitable as a habitat for their aquatic stages and distributed in all zoogeographical regions. According to the last version of the Inventory of the world's Simuliidae, the family includes 26 genera and 2351 species (2335 living and 16 fossils) [1]. The females of most black fly species feeding on blood of humans, mammals and birds being the main vectors of some human and animal pathogens. Among the blood-borne parasites most commonly transmitted by black flies are the blood protozoan of the genera Leucocytozoon that cause leucocytozoonosis in birds, the filarioid nematodes of the genus Onchocerca that cause human onchocerciasis, mansonellosis and bovine onchocerciasis and viruses like vesicular stomatitis in cattle and horses. Some of these diseases cre- 
ate severe economic declines and public health threats [5]. Larvae and pupae are aquatic and may be used as water quality indicators [3].

To the best of our knowledge, the data on black fly fauna in Moldova are absent in the old and modern literature. The closest well known black fly faunas of Romania and Ukraine consist of approximately 102-111 species belonging to six genera such as Prosimulium, Metacnephia, Twinnia, Cnephia, Simulium and Stegopterna [1]. Overall, 71 black fly species from three genera (Prosimulium, Metacnephia and Simulium) were recorded in Romania, including eight species which presence in the country is questionable $[1 ; 2 ; 4]$. In total, 92 black fly species belonging to five genera (Prosimulium, Twinnia, Cnephia, Simulium and Stegopterna) were recorded in Ukraine (species from Crimean peninsula have not been excluded from the list) $[1 ; 6 ; 7 ; 10]$. Overall, 45 black fly species from the genera Prosimulium (four species) and Simulium (41 species) such as Prosimulium hirtipes (Fries, 1824), P. latimucro (Enderlein, 1925), P. rufipes (Meigen, 1830), P. tomosvaryi (Enderlein, 1921), Simulium erythrocephalum (De Geer, 1776), S. maculatum (Meigen, 1804), S. angustipes Edwards, 1915, S. aureum Fries, 1824, S. krymense (Rubtsov, 1956), S. rubzovianum (Sherban, 1961), S. angustitarse (Lundström, 1911), S. angustatum (Rubtsov, 1956), S. codreanui (Sherban, 1958), S. costatum Friederichs, 1920, S. crenobium (Knoz, 1961), S. vernum Macquart, 1826, S. nigrum (Meigen, 1804), S. argenteostriatum Strobl, 1898, S. bezzii (Corti, 1914), S. bukovskii Rubtsov, 1940, S. noelleri Friederichs, 1920, S. baracorne Smart, 1944, S. deserticola Rubtsov, 1940, S. frigidum Rubtsov, 1940, S. intermedium Roubaud, 1906, S. kiritshenkoi Rubtsov, 1940, S. ornatum Meigen, 1818, S. rotundatum (Rubtsov, 1956), S. reptans (Linnaeus, 1758), S. voilense Sherban, 1960, S. vulgare Dorogostaisky, Rubtsov, Vlasenko, 1935, S. argyreatum Meigen, 1838, S. maximum (Knoz, 1961), S. monticola Friederichs, 1920, S. monticoloides (Rubtsov, 1956), S. variegatum Meigen, 1818, S. morsitans Edwards, 1915, S. paramorsitans Rubtsov, 1956, S. auricoma Meigen, 1818, S. balcanicum (Enderlein, 1924), S. equinum (Linnaeus, 
1758), S. lineatum (Meigen, 1804), S. paraequinum Puri, 1933, S. pseudequinum Séguy, 1921 and S. veltistshevi Rubtsov, 1940 are common both for Romania and Ukraine and expected to be present in Moldova [1]. Moreover, 44 valid species were reported from Ukraine, which have not been registered in Romania and approximately 18-25 species recorded in Romania have not been found in Ukraine. Due to the absence of any old and recent data on black fly species diversity, spatial distribution and public health importance in Moldova, new surveys are particularly needed in the country.

\section{MATERIALS AND METHODS}

For the first time cross-sectional entomological survey was conducted between May and August 2018 to detect the aquatic habitats of Simuliidae at 15 localities (Plaiul Fagului, Zberoaia, Grozesti, Vascauti, Saharna, Rezina, Ciorna, Costesti, Duritoarea Noua, Branzeni, Burlanesti, Sturzovca, Tomai, Ceadir-Lunga, Corten) from nine regions (Calarasi, Nisporeni, Orhei, Rezina, Rascani, Glodeni, Edinet, Ceadie-Lunga, Taraclia) in Moldova. Each creek and river section (30-40 m) was sampled once from downstream to upstream by two people during 1-2 hours. For each breeding site the following characteristics were recorded: depth $(\mathrm{m})$, width $(\mathrm{m})$, water temperature $\left({ }^{\circ} \mathrm{C}\right)$, water salinity (PSU) and $\mathrm{pH}$. Each collected site was numbered and mapped using global positioning system (GPS). Larvae attached to the vegetation and stones were collected by pincette and transferred to $96 \%$ and then to $70 \%$ ethanol solution. Pupae attached to the same substrates were collected together with a piece of substrate (leaf, stem) and transferred to the plastic containers. In laboratory, the mature pupae still attached to the substrate were individually kept alive in vials with highly wet atmosphere until the emerging of the adults from their cocoons. In total, more than 200 adult specimens have been obtained from about 500 pupae. The adults together with their pupal 
exuviae and cocoons were kept in $96 \%$ ethanol for further species identification. Permanent slides have been prepared from male genitalia, legs, wings and the heads. At present the black fly adults are subjected to the species identification according to taxonomic keys of Rubtsov (1956), Rubtsov and Yankovsky (1984) and Yankovsky (2001) [8; 9; 11]

\section{RESULTS AND DISCUSSIONS}

Productive breeding sites of black flies were identified in the creek close to the Dniester River section located in Vascauti village, Racovat River sections located in Branzeni and Burlanesti villages. Immature stages of black flies also have been found in the small creeks in Chisinau and Duruitoarea Veche. In the creek and river habitats with running water where the bottom was sandy/muddy the immature stages were found attached only to the leaves and branches of aquatic plants like Potamogeton spp. In the river sections with stony bottom structure immature stages were also found attached to the submerged stones. The high densities of immature stages were found on vegetation substrates not deeper than 10 $\mathrm{cm}$ below the water surface at water temperature $24-28^{\circ} \mathrm{C}$ in Racovat River and the creeks in Chisinau. Due to a high plastic pollution of streams in Chisinau, Simuliidae immature stages were also found attached to the plastic cups. Immature stages of black flies were absent in the creeks with cold running water (about $18^{\circ} \mathrm{C}$ ) located in Saharna and Ciorna villages, where Anopheles claviger Meig. larvae have been collected. In our surveys black flies also have not been found in the rivers Prut and Dniester most probably because of the low speed of water flow, but further surveys are needed. The Simuliidae generally inhabit unpolluted running water, being the important components of the stream ecosystem and having the ability to filter dissolved organic matter. Simuliidae larvae and pupae are susceptible to organic and inorganic pollution and may play an important role in the monitoring of freshwater contamination [3]. 


\section{CONCLUSIONS}

Preliminary results revealed the presence of black flies in some aquatic habitats in Moldova, which physicochemical parameters were suitable for immature Simuliidae. Further surveys in the region and the results of species identification will help to understand the Simuliidae species diversity in the Republic of Moldova, breeding habitat preferences, spatial distribution and public health and veterinary importance of black flies as vectors of vector-borne diseases.

\section{BIBLIOGRAPHY}

1. Adler PH, Crosskey RW. World blackflies (Diptera: Simuliidae): a comprehensive revision of the taxonomic and geographical inventory. 2018. https://biomia.sites. clemson.edu/pdfs/blackflyinventory.pdf. (Accessed 04 Jul 2018)

2. Dinulescu G. Fauna Republicii Socialiste Romania. Insecta, Diptera, Fam. Simuliidae. Editura Academiei Republicii Socialiste Romania, 1966. Bucuresti, 604 pp.

3. Feld CK, Kiel E, Lautenschläger M. The indication of morphological degradation of streams and rivers using Simuliidae. Limnologica. 2002; 32: 273-288.

4. Kúdela M, Stloukalová V. New records of blackflies (Diptera: Simuliidae) from Romania. Entomol. Rom. 2007;12: 203-206.

5. Marquardt W., et al. Biology of disease vectors. California, 2005. 785 p.

6. Аебедева ^.И.Мошки (Diptera, Simuliidae) центральной и восточной части Полесья Украины: Автореф. Аис. .канА. биол. наук: 03.106.- Киев, 1970.- 25 с

7. Петрова К. К. Мошки северной части Украины // Сб. ст. по зоологии. Краснодар, 1967. - C. 71-76.

8. Рубцов И. А. Мошки (сем. Simuliidae) // Фауна СССР. Авукрылые.- М.;^., 1956. Т. 6. - Вып. 6. - 860 с.

9. Рубцов И. А., Янковский А. В. Определитель родов мошек Палеарктики. ^.: Наука, 1984. - 176 с.

10.Шевченко А. К., Са^о 3. Т. Кровососущие мошки (Diptera, Simuliidae) Полесья Украины // Мед. паразитол. и паразитарн. болезни. 1969.- Т. 38, № 1.-С. 16-21.

11.Янковский А. В. Определитель мошек (Diptera:Simuliidae) России и сопредельных территорий (бывшего СССР). С-П.: ЗИНРАН, 2002. - 570 с. 